\title{
THE INTERACTIONS AND TRADE-OFFS OF SOVEREIGN CREDIT DEFAULT SWAP (CDS) AND BOND SPREADS IN A DYNAMIC CONTEXT
}

\author{
Ioannis A. TAMPAKOUDIS ${ }^{1}$, Andrius TAMOŠIŪNAS ${ }^{2}$, \\ Demetres N. SUBENIOTIS ${ }^{3}$, Ioannis G. KROUSTALIS ${ }^{4}$ \\ 1, 3, ${ }^{4}$ Department of Business Administration, University of Macedonia, Thessaloniki, Greece \\ ${ }^{2}$ Department of Management, Vilnius Gediminas Technical University, Vilnius, Lithuania
}

Received 15 May 2018; accepted 11 February 2019

\begin{abstract}
This study provides a dynamic analysis of the lead-lag relationship between sovereign Credit Default Swap (CDS) and bond spreads of the highly indebted southern European countries, considering an extensive time sample from the period before the global financial crisis to the latest developments of the sovereign indebtedness in the euro area. We employ an integrated price discovery methodology on a rolling sample, with the intention of investigating the efficient pricing of credit risk in the CDS and bond markets and the possibility of CDS spreads causing rises in bond spreads. In addition, we attempt to depict the evolution of the price discovery process regarding the direction of influence from one market to the other. The rolling window analysis verifies that the price discovery process evolves over time, presenting frequent alternations concerning the leading market. We find that during periods of economic turbulence the CDS market leads the bond market in price discovery, incorporating the new information about sovereign credit risk faster and more efficiently than the bond market does. This regularity should be seriously considered by private and public participants as they make investment and funding decisions. Therefore, the motivation of our paper is to identify the dominant market in terms of price discovery during a period of economic turmoil and, thus, to provide insights for decision making to investment bodies and central governments.
\end{abstract}

Keywords: credit risk, CDS, sovereign bonds, debt crisis, cointegration, Granger causality, price discovery.

JEL Classification: C13, F34, G12, G14, G15, M16, M48, M21, M29.

\section{Introduction}

Credit default swaps (CDS) are over-the-counter derivative instruments that provide market participants with an alternative and unfunded channel of credit risk trade. Bondholders are able to transfer their investment's credit risk to a third party by buying the suitable CDS

*Corresponding author. E-mail: andrius.tamosiunas@vgtu.lt 
contract, whereas speculators can bet on the deterioration of an issuer's creditworthiness by taking naked CDS positions. CDS and bond spreads are highly related, since both are measures of the credit risk associated with a bond issuer (for more on credit risk quantification see Klieštik \& Cúg, 2015). Theoretically, CDS spreads and the underlying bond spreads must be almost equal (Duffie, 1999; Hull \& White, 2000; Hull, Predescu, \& White, 2004; Cossin \& Lu, 2005; Coudert \& Gex, 2013) considering that they reflect similar information regarding the creditworthiness of a given corporate or sovereign reference entity. However, this condition never holds in practice since the two contracts do not match perfectly (Longstaff, Mithal, \& Neis, 2003; Blanco, Brennan, \& Marsh, 2005; Coudert \& Gex, 2010, 2013). Given that, the issue of which spread influences the other, i.e. which spread leads the pricing process, constitutes a favorable research area since it has an effect on the behavior of investors, policy makers and regulators.

The vast majority of studies in the field focuses on corporate credit markets, supporting the leading role of CDS in the pricing process (Longstaff et al., 2003; ECB, 2004; Blanco et al., 2005; Zhu, 2006; Baba \& Inada, 2007; Forte \& Pena, 2009; Norden \& Weber, 2009; Klenina \& Mateus, 2017). As far as sovereign reference entities are concerned, the studies focusing on developing countries yielded contradictory findings (Chan-Lau \& Kim, 2004; Bowe, Klimaviciene, \& Taylor, 2009; Ammer \& Cai, 2011; Aktug, Vasconcellos, \& Bae, 2012; Hassan, Ngene, \& Suk-Yu, 2015; Kregzde \& Murauskas, 2015). The assessment of the relation between CDS and bond spreads for developed sovereign reference entities held no significant research interest until recently, mainly owing to inconsiderable perceived credit risk and trading volume in the respective CDS market. The 2007-09 financial crisis along with the subsequent Eurozone crisis increased financial market linkages (Yin, Z. Liu, \& P. Liu, 2017). In that context, the risk of default of the developed countries was fundamentally reassessed. CDS and bond spreads, particularly in the heavily indebted Eurozone countries, increased substantially and so did the trading activity in the CDS market. As a result, a new stream of literature emerged, focusing on the price discovery process in sovereign credit markets of developed countries with the intention of detecting whether rises in CDS spreads can trigger rises in bond spreads (Group of 20, 2009; Palladini \& Portes, 2011; Delatte, Gex, \& López-Villavicencio, 2012; Coudert \& Gex, 2013; Andraz, Viegas, \& Norte, 2015; Fontana \& Scheicher, 2016; Ito, 2016; Nguyen, 2017). Nevertheless, just as in the case of developing countries, these studies have failed to provide converging findings.

The implicit assumption of a stable price discovery process continuously occurring in the same direction (presented in most studies) may seem rather unrealistic (Delatte et al., 2012). The few studies which follow dynamic empirical approaches reveal that the price discovery process evolves over time based on market perceptions of credit risk (Delis \& Mylonidis, 2011; Arce, Mayordomo, \& Peña, 2013). However, these studies employ single price discovery measures rather than an integrated price discovery methodology. Thus, there is lack in the literature with regard to the investigation of the lead-lag relationship between sovereign CDS and bond spreads in a dynamic context.

Considering the stylized facts in the literature, the purpose of this paper is twofold. Firstly, to investigate the lead-lag relationship between CDS and bond spreads of the highly indebted Eurozone countries in a time-varying context. Secondly, to depict the evolution of 
the price discovery process in each country, detecting potential alternations in the leading market and, thus, assist market participants and policy makers in their decision-making process. The object of the paper is to examine the interrelation between sovereign CDS and bond markets of the selected countries applying rolling window estimation techniques on the respective spreads. We employ an integrated price discovery methodology to identify which market is the leading one, as well as to determine the evolution pattern of the price discovery process concerning the dominant market. The price discovery methodology of our research is implemented through a three-step procedure. The first step examines the stationarity of the series and, in case both series are integrated in the same order, the Johansen cointegration test is applied. In the third step and based on the existence of cointegration, we apply either a Vector Error Correction Model (VECM) or the Granger causality test to determine the leading market in price discovery. The novelty of the paper lies in the methodological procedure and the derived policy implications. To our knowledge, this is the first study that investigates the relation between CDS and bond spreads during the Eurozone debt crisis applying an integrated three-step methodology on a sequence of subsamples. The dynamic approach allows us to relate any alternations in price discovery to specific episodes of the European debt crisis that may have affected the market perceptions of sovereign credit risk. Our evidence suggests that price discovery is a dynamic process exhibiting frequent alternations in terms of leadership. The results indicate the regularity that, during periods of increased financial uncertainty, the CDS market leads the price discovery process incorporating new information about sovereign credit risk, faster and more efficiently than the bond market does. Taking into account this information, governments could take appropriate measures to curb their borrowing costs, while regulators could assess the sovereign credit markets in terms of efficiency and transparency. In particular, governments could respond to CDS spread increases using austerity measures to meet budget targets and repair public finances. Austerity measures include reductions in public spending and/or increases in tax revenues. Governments can cut spending reducing the number, wages and benefits of civil servants, curtailing pension and health care benefits, raising the eligibility age for retirement and limiting public welfare programs. Increases in tax revenues can be achieved by raising income taxes (especially on the wealthy), increasing the Value Added Tax (VAT) and the corporate tax rate, tackling tax evasion and selling state-owned assets and enterprises. Other austerity measures include labour market reforms aiming to lower business costs and, thus, enhance private sector competitiveness. Austerity measures restore market confidence, demonstrating a country's willingness to strengthen financial discipline, which in turn prevents an increase in sovereign bond yields. With regard to market participants, they could follow the patterns of price discovery, in order to implement their investing, hedging or speculative strategies. Increases in sovereign CDS spreads should force investors that hold the corresponding government bonds to sell them immediately or to take hedged positions selling bond futures. In the latter case, the price drop of the bond portfolio would be offset by a gain in the value of the short position in bond futures, considering that bond spreads are expected to follow the increase of CDS spreads. Speculators that anticipate interest rate jumps due to soaring CDS spreads might short sell sovereign bonds or take leveraged positions selling bond futures. 
The remainder of the paper is organized as follows. In Section 1, we review the related literature. Section 2 analyzes the data and describes the applied methodology. Section 3 discusses the main findings. Lastly, the paper highlights the main findings and their implications, identifies possible limitations, and makes suggestions for future research.

\section{Prior literature}

The investigation of the relation between CDS and bond markets and more specifically the identification of the leading one in the price discovery process has attracted intense research interest in recent years. The early literature concentrates on corporate credit markets, while government entities are only later assessed. The former examine corporate entities mainly from the US and Europe, while few studies consider entities from the rest of the world. In particular, Longstaff et al. (2003) examining 68 North American firms that are actively traded in the credit derivatives market, assert that new information is firstly incorporated into the CDS and stock markets and then into the bond market. Zhu (2006) and Blanco et al. (2005), studying a sample of 24 and 33 firms respectively, verify that CDS and bond spreads are in a long-run parity relation, while deviations from the equilibrium in the short-run are mainly attributed to the leading role of CDS in price discovery. Similarly, Forte and Pena's (2009) empirical analysis of firms from North America and Europe, also verifies the leading role of CDS. Norden and Weber (2009), analyzing a sample of 58 corporates, confirm that CDS and bond spreads are cointegrated in most of the examined entities. They suggest that the CDS market contributes more in the pricing process compared to the bond market, while this effect is more evident for firms in the US than for firms in Europe. Lee, Naranjo, and Velioglu (2017) utilize an extensive sample of US corporate entities, showing that CDS spreads contain unique information about credit risk that is not captured by other security markets. According to the authors, the prominence of this firm-specific information promotes the leadership of CDS spreads in price discovery. The study of the ECB (2004), focusing on the European corporate credit markets, confirms the existence of cointegration and the leading role of the CDS market for the majority of the examined entities. Trujillo-Ponce, SamaniegoMedina, and Cardone-Riportella (2013), studying a sample of 51 European firms, find that CDS spreads act as efficient credit risk indicators, especially during periods of crisis. Baba and Inada (2007), considering a sample of Japanese banks, find that CDS and bond spreads are cointegrated in most cases. In addition, the authors verify that in general the CDS spread plays a dominant role in the price discovery process. Last but not least, Klenina and Mateus (2017) investigate the price discovery process in corporate credit markets before, during and after the 2007-08 financial crisis for a sample of 697 UK firms. They conclude that changes in CDS spreads cause changes in bond spreads, since the former react faster on credit risk information flows.

With regard to credit markets of sovereign entities, early literature focuses on developing economies and seems to present a different picture. Chan-Lau and Kim (2004) provide conflicting findings regarding the existence of cointegration and price discovery leadership, considering eight developing sovereigns for the period 2001-2003. Ammer and Cai (2011) analyze daily data from nine sovereigns, highlighting liquidity as a decisive factor of the 
leading market in price discovery. The authors suggest that the CDS market is less likely to be the leading one for large sovereign issuers. Aktug et al. (2012), considering 30 developing countries from 2001 to 2007, support the leading role of the bond market in the pricing process. Similar findings reveal Bowe et al. (2009), studying eight emerging markets from 2003 to 2006. Hassan et al. (2015) and Coudert and Gex (2013) examine similar samples of emerging sovereign countries, taking into account the recent growing sovereign indebtedness. Both studies confirm that cointegration exists for all credit markets. However, they conclude that in most cases CDS markets lead the price discovery process by adjusting the new information more timely than the bond markets do. Lastly, Kregzde and Murauskas (2015), analyzing the Lithuanian sovereign CDS market from 2010 to 2013, find that under stressful conditions the bond market leads the price discovery process. Contrarily, as the sovereign risk falls, the leading role is taken by the CDS market.

The global financial crisis of 2007-08 and the European debt crisis that followed renewed the research interest in the developed sovereign credit markets. Gyntelberg, Hördahl, Ters, and Urban (2017), examining the credit markets of seven euro area countries from 2008 to 2010, find that the speed of adjustment towards the long-run equilibrium increases once the CDS-bond basis exceeds a certain level. Fontana and Scheicher (2016) analyzing 10 Eurozone sovereigns from 2006 to 2010, suggest that from the end of 2008 in core Europe price discovery occurs in the bond market, while the contrary seems to happen in the periphery. Coudert and Gex (2013) reveal similar results, while Palladini and Portes (2011) find that over the period from 2004 to 2011 both in core and periphery countries the CDS market appears to move ahead of the bond market in the pricing process. Delatte et al. (2012), considering 11 European sovereigns for the period 2008-2010, provide evidence of non-linearity in the relation between CDS and bond spreads. They also find that the CDS market dominates the information transmission between CDS and bond markets in periods of financial distress. Similar results are provided by the study of Nguyen (2017), which focuses on the global crisis period and beyond (2008-2017), analyzing a sample of three European and two Asian countries.

All the aforementioned studies apply their empirical methodology using the entire sample period at once. They implicitly assume that the relation between CDS and bond spreads is constant and the price discovery process is continuous and of stable intensity. According to Delatte et al. (2012), the assumption that the influence from one market to the other occurs continuously in the same direction is rather unrealistic. Instead, there are indications that the leading market in price discovery is determined by the level of credit risk perceived by market participants over time. Indeed, the conflicting findings of the existing literature on sovereign credit markets reinforce the above proposition. In this perspective, Delis and Mylonidis (2011) study the dynamic interrelation between CDS and bond spreads in southern European countries on the basis of a rolling Granger causality test. The authors find causality from CDS to bond spreads since 2007, while they observe feedback causality during periods of increased economic uncertainty. Similarly, Arce et al. (2013) apply a dynamic analysis on 11 euro area sovereigns from 2004 to 2012, asserting that the recent sovereign indebtedness resulted in the deterioration of the ability of the CDS market to undertake the leading role in price discovery. Evidently, the empirical results referring to sovereign credit markets are 
contradictory, especially for advanced economies. In addition, the current growing sovereign indebtedness of the southern European countries has brought to light new fundamentals in the sovereign credit markets, whereas there are strong indications that the relation between CDS and bond markets is not constant, but it evolves over time (Delis \& Mylonidis, 2011; Delatte et al., 2012; Arce et al., 2013). In that frame, we examine the lead-lag relationship between CDS and bond spreads in a time-varying context, focusing on the peripheral European countries that were in the epicenter of the sovereign debt crisis. For this reason, we employ a rolling window approach to investigate the price discovery mechanism between CDS and bond markets over the period 2006-2015.

Our study is similar to the aforementioned studies in exploring the relationship between European sovereign CDS and bond markets. However, our tests and empirical findings complement and expand these studies in several ways. First, previous research following rolling approaches utilizes either the Granger causality test (Delis \& Mylonidis, 2011) or the Gonzalo and Granger measure (Arce et al., 2013). To the best of our knowledge, this study is the first using the two measures interchangeably, applying an integrated three step methodology on a sequence of subsamples. This methodological approach detects potential alternations in the leading market, indicating that the price discovery process is neither continuous nor constant. Second, the sample period in this study is considerably larger than the sample in previous studies. Our relatively large sample allows us to investigate for the first time the price discovery process prior to, during and after the global financial crisis. The crisis itself offers a quasi-experimental setting providing the opportunity for a clear test of the interrelation between CDS and bond markets. Therefore, we can interpret and validate our findings from periods with different economic and financial contexts including the European sovereign debt crisis. Such analysis is important to investigate specific phases of the crisis and detect structural changes in the price discovery process for each of the over-indebted European countries. Similarly, this is the first study that investigates the relationship between CDS and bond spreads for the indebted countries of south Europe in comparison to other Eurozone countries with more advanced credit markets over an extended period including the latest episodes of the European sovereign crisis. Prior studies analyze heterogeneous samples in terms of geographical area (Nguyen, 2017), focus on the Southern European countries (Delis \& Mylonidis, 2011), or examine large samples of European countries until the peak of the crisis (Delatte et al., 2012; Arce et al., 2013). The examination of the relationship between sovereign CDS and bond markets of peripheral along with core European countries over a ten-year period is expected to lead to robust findings with regard to the evolution of CDS and bond price dynamics in the euro area.

\section{Data and methodology}

\subsection{Data and sample}

For our study we use five-year daily CDS spreads and five-year daily bond yields for four southern Eurozone countries, namely Portugal, Italy, Greece and Spain, as well as for two core Eurozone countries, namely France and Austria. Consistently with the literature, we 
select maturity of five years, since it represents the most liquid and actively traded sovereign CDS market segment. The sample period for Portugal, Italy, France and Austria runs from January 2006 to March 2015. In the case of Spain the sample period runs from October 2006 to March 2015, while for Greece the sample period begins in January 2006 and ends in September 2011, owing to lack of data availability and missing observations. For comparability purposes and in line with previous studies on European sovereign credit markets (Palladini \& Portes, 2011; Delis \& Mylonidis, 2011; Delatte et al., 2012; Arce et al., 2013; Coudert \& Gex, 2013; Fontana \& Scheicher, 2016; Gyntelberg et al., 2017), we compute the bond spreads over the German Bund which is considered to be the benchmark risk-free rate for the euro area. Given that we use reference sovereign bond yields rather than generating synthetic bond yields (for more, see Beber, Brandt, \& Kavavejc, 2009; Ammer \& Cai, 2011; Kregzde \& Murauskas, 2015; Ngene, Benefield, \& Lynch, 2018), the yield of the German government bond represents the appropriate base rate to construct bond yield spreads comparable to CDS spreads as credit risk measures. Both CDS and bond data are retrieved from Bloomberg.

\subsection{Methodology}

\section{Preliminary analysis}

In order to examine the relation between CDS and bond spreads we apply a three-step methodology. Firstly, we check the stationarity of the series. In case unit root is detected in both CDS and bond spread series and they are integrated in the same order, we proceed to the second step where we employ the Johansen cointegration test (Johansen, 1991) in order to examine whether a long-run relation holds between the two spreads. In the third step, and provided that cointegration exists, we utilize a Vector Error Correction Model (VECM) to investigate the price discovery process. Alternatively, if cointegration does not exist, we employ the Granger causality test (Granger, 1969) to determine the direction of influence between CDS and bond spreads. ADF unit root test (Dickey \& Fuller, 1979) is performed to check the stationarity of the series. Additionally, we apply the Zivot-Andrews unit root test (Zivot \& Andrews, 1992) which allows for an endogenously estimated breakpoint in the trend function of the series under the alternative hypothesis. Given that both CDS and bond series are non-stationary, we apply the cointegration test. The confirmation of cointegration between two non-stationary series implies the existence of a stationary linear combination; thus, the series can be analyzed using a vector autoregressive (VAR) model (Greene, 2003; Gujarati, 2003; Jeffrey, 2009). The Johansen (1991) cointegration test provides the cointegrating vectors and estimates consistently the cointegrating matrix. The rejection of the null hypothesis of no cointegration implies the existence of a long-run equilibrium relation between the two spreads.

Moving to the second step and provided the existence of cointegration, a Vector Error Correction Model (VECM) is employed in order to specify the short-run dynamics on the cointegrated spreads' series, since they can temporarily deviate from the equilibrium relationship that is specified as follows:

$$
\text { CDS } \text { spread }_{t}=\alpha+\beta \text { bond } \text { spread }_{t}+z_{t} .
$$


Rearranging equation (1), we have:

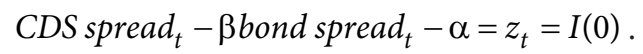

The long-run relation is determined by coefficient $\beta$, while has to be stationary ().

$$
\begin{aligned}
& \Delta C D S \text { spread }_{t}=c_{1}+\alpha_{1} z_{t-1}+\sum_{j=1}^{p} \gamma_{1 j} \Delta C D S \text { spread }_{t-j}+\sum_{j=1}^{p} \delta_{1 j} \Delta \text { bond spread }_{t-j}+\varepsilon_{1 t} \\
& \Delta{\text { bond } \text { spread }_{t}=c_{2}+\alpha_{2} z_{t-1}+\sum_{j=1}^{p} \gamma_{2 j} \Delta \text { CDS spread }}_{t-j}+\sum_{j=1}^{p} \delta_{2 j} \Delta \text { bond spread }_{t-j}+\varepsilon_{2 t} .
\end{aligned}
$$

Considering the VECM we focus on the speed of adjustment or error correction coefficients, $\alpha_{1}$ and $\alpha_{2}$, that represent the price discovery measures. The magnitudes and the signs of alphas are accounted in order to determine the leading market in the price discovery process in the short-run. A significantly negative $\alpha_{1}$ implies that the CDS spread adjusts towards the long-run equilibrium to close the gap and, thus, the bond spread leads the pricing process. In contrast, if $\alpha_{2}$ is significant and positive, the bond spread is the adjusting one; therefore, the price discovery leadership is attributed to the CDS spread. Lastly, if both coefficients are significant and correctly signed, then both the CDS and bond markets contribute to price discovery. In such a case, the efficient price is firstly discovered in the slower adjusting market. We employ the Gonzalo-Granger measure (Gonzalo \& Granger, 1995), which is defined as: $G G=\alpha_{2} /\left(\alpha_{2}-\alpha_{1}\right)$, to assess the relative importance of the two markets in the price discovery process.

In case there is no evidence of cointegration, the lead-lag relation between CDS and bond markets is investigated with the Granger (1969) causality test, since the VECM specification is not valid. In this framework, a $\operatorname{VAR}(p)$ model is estimated in level form if the examined series are stationary or in first differences form if unit root is detected. Granger causality from CDS spread to bond spread implies that price discovery occurs in the CDS market and vice versa. In case bilateral causality is detected, price discovery occurs in both markets. We also apply the bootstrap Granger causality test proposed by Toda and Yamamoto (1995). This method is applicable regardless of whether the series in question are integrated or cointegrated of an arbitrary order.

\section{Rolling window analysis}

Intending to extend the standard price discovery analysis to a dynamic context, we apply the above three-step methodological procedure using rolling windows with the fixed length of 250 daily observations (approximately a calendar year). Rolling window estimation techniques use a fixed length window that moves sequentially from the beginning to the end of the sample, by adding one observation to the end and removing the beginning one. This methodology provides a sequence of estimated parameters and test statistics, allowing the detection of structural changes in the examined relationship over time (Mylonidis \& Kollias, 2010; Delis \& Mylonidis, 2011; Kollias, Mylonidis, \& Paleologou, 2012; Arce et al., 2013). Furthermore, this approach addresses the issue of subsample instability by considering a sequence of subsamples (Swanson, 1998; Nyakabawo, Miller, Balcilar, Das, \& Gupta, 2015). 
We consider a sequence of 2,145 subsamples (starting with 02/01/2006 - 15/12/2006 and ending with 21/03/2014 - 05/03/2015) for Portugal, Italy, France and Austria, 1,930 subsamples (starting with 23/10/2006 - 5/10/2007 and ending with 17/03/2014 - 27/02/2015) for Spain and 1,240 subsamples (starting with 02/01/2006 - 15/12/2006 and ending with $01 / 10 / 2010$ - 15/09/2011) for Greece. Summing up, we apply the standard three-step methodological procedure almost 12,000 times considering the sum of subsamples for all the examined countries.

\section{Empirical results and discussion}

This section presents the findings of the dynamic empirical procedure on the selected sovereign credit markets.

\section{Preliminary results}

The ADF unit root test indicates that all the examined series are integrated in the first differences (Tables 1-4). Considering the Zivot-Andrews test, the unit root null hypothesis is rejected for both CDS and bond spread series, indicating trend stationarity with a breakpoint (Tables 1-4). The estimated breakpoints in CDS spreads occur in February 2011 for Portugal, in July 2011 for Italy, Spain and France, in October 2010 for Greece, and in July 2012 for Austria. Respectively, the breakpoints in bond spreads are identified in March 2011 for Portugal, in July 2011 for Italy and France, in July 2009 for Greece, in March 2012 for Spain and in June 2012 for Austria.

Table 1. CDS spread unit root tests

\begin{tabular}{|l|l|l|c|c|c|c|}
\hline \multirow{2}{*}{ Test statistic } & \multicolumn{3}{|c|}{ ADF test } & \multicolumn{3}{c|}{ Zivot-Andrews test } \\
\cline { 3 - 7 } \multicolumn{2}{|c|}{} & Unit Root & Test statistic & Unit Root & Breakpoint & \\
\hline \multirow{3}{*}{ Portugal } & level & $-1.098(0.928)$ & Yes & $-4.153(0.000)$ & No & $02 / 02 / 2011$ \\
\cline { 2 - 7 } & $1^{\text {st diff. }}$ & $-28.646(0.000)$ & No & - & - & - \\
\hline \multirow{3}{*}{ Italy } & level & $-1.672(0.763)$ & Yes & $-6.526(0.000)$ & No & $05 / 07 / 2011$ \\
\cline { 2 - 7 } & $1^{\text {st diff. }}$ & $-34.519(0.000)$ & No & - & - & - \\
\hline \multirow{3}{*}{ Greece } & level & $1.724(1.000)$ & Yes & $-3.204(0.000)$ & No & $25 / 10 / 2010$ \\
\cline { 2 - 7 } & $1^{\text {st diff. }}$ & $-7.117(0.000)$ & No & - & - & - \\
\hline \multirow{2}{*}{ Spain } & level & $-1.112(0.926)$ & Yes & $-4.460(0.000)$ & No & $05 / 07 / 2011$ \\
\cline { 2 - 7 } & $1^{\text {st diff. }}$ & $27.633(0.000)$ & No & & & \\
\hline \multirow{2}{*}{ France } & level & $-1.376(0.868)$ & Yes & $-5.143(0.000)$ & No & $06 / 07 / 2011$ \\
\cline { 2 - 7 } & $1^{\text {st diff. }}$ & $-29.516(0.000)$ & No & & & \\
\hline \multirow{2}{*}{ Austria } & level & $-2.006(0.597)$ & Yes & $-4.083(0.000)$ & No & $10 / 07 / 2012$ \\
\cline { 2 - 7 } & $1^{\text {st diff. }}$ & $-36.572(0.000)$ & No & - & - & - \\
\hline
\end{tabular}

Note: This table presents the results of the ADF and Zivot-Andrews unit root tests in CDS spreads. In parenthesis are reported the $p$-values. 
Table 2. Bond spread unit root tests

\begin{tabular}{|l|l|c|c|c|c|c|}
\hline \multirow{2}{*}{ Test statistic } & \multicolumn{2}{|c|}{ ADF test } & \multicolumn{3}{c|}{ Zivot-Andrews test } \\
\cline { 3 - 7 } \multicolumn{2}{|c|}{} & Unit Root & Test statistic & Unit Root & Breakpoint & \\
\hline \multirow{2}{*}{ Portugal } & level & $-0.951(0.949)$ & Yes & $-5.077(0.000)$ & No & $22 / 03 / 2011$ \\
\cline { 2 - 7 } & $1^{\text {st diff. }}$ & $-16.478(0.000)$ & No & - & - & - \\
\hline \multirow{2}{*}{ Italy } & level & $-1.369(0.870)$ & Yes & $-6.514(0.000)$ & No & $05 / 07 / 2011$ \\
\cline { 2 - 7 } & $1^{\text {st diff. }}$ & $-28.189(0.000)$ & No & - & - & - \\
\hline \multirow{2}{*}{ Greece } & level & $0.973(0.999)$ & Yes & $-3.106(0.002)$ & No & $14 / 07 / 2009$ \\
\cline { 2 - 7 } & $1^{\text {st } \text { diff. }}$ & $-22.245(0.000)$ & No & - & - & - \\
\hline \multirow{2}{*}{ Spain } & level & $-1.268(0.895)$ & Yes & $-4.792(0.000)$ & No & $20 / 03 / 2012$ \\
\cline { 2 - 7 } & $1^{\text {st diff. }}$ & $-28.998(0.000)$ & No & - & - & - \\
\hline \multirow{2}{*}{ France } & level & $-3.237(0.077)$ & Yes & $-6.688(0.000)$ & No & $28 / 07 / 2011$ \\
\cline { 2 - 7 } & $1^{\text {st diff. }}$ & $-55.237(0.000)$ & No & - & - & - \\
\hline \multirow{2}{*}{ Austria } & level & $-3.060(0.116)$ & Yes & $-5.511(0.000)$ & No & $13 / 06 / 2012$ \\
\cline { 2 - 7 } & $1^{\text {st } \text { diff. }}$ & $-51.546(0.000)$ & No & - & - & - \\
\hline
\end{tabular}

Note: This table presents the results of the ADF and Zivot-Andrews unit root tests in bond spreads. In parenthesis are reported the $p$-values.

Given that all series are first-order integrated we test for cointegration between CDS and bond spreads. The Johansen cointegration test indicates the rejection of the null hypothesis of no cointegration in all cases (Table 3), implying that a long-run equilibrium exists between CDS and bond spreads.

Table 3. Cointegration Test (full sample)

\begin{tabular}{|l|c|c|c|}
\hline & Trace statistic & Max-eigenvalue statistic & Cointegration \\
\hline Portugal & $41.692(0.000)$ & $39.613(0.000)$ & Yes \\
\hline Italy & $37.793(0.000)$ & $34.725(0.000)$ & Yes \\
\hline Greece & $20.318(0.009)$ & $13.193(0.073)$ & Yes \\
\hline Spain & $23.670(0.002)$ & $20.050(0.006)$ & Yes \\
\hline France & $40.959(0.000)$ & $37.785(0.000)$ & Yes \\
\hline Austria & $57.111(0.000)$ & $52.078(0.000)$ & Yes \\
\hline
\end{tabular}

Note: This table reports the results of the Johansen cointegration test. The optimal lag-length of the VAR models is determined through the Schwarz information criteria (SC). Columns 2 and 3 display the trace and maximum eigenvalue statistics of the test, respectively. In parenthesis are reported the $p$-values.

The cointegrated series are considered in a VECM specification to determine the process of adjustment in the short-run. The results that are reported in Table 4 provide evidence of CDS market leadership for Portugal, Italy, Spain and France. In the case of Austria, the bond market is found to lead in price discovery, while for Greece the leading market cannot be identified. 
Table 4. Price discovery measures (full sample)

\begin{tabular}{|c|c|c|c|c|c|}
\hline & & Coeff. & t-statistic & GG & Leading Market \\
\hline \multirow{2}{*}{ Portugal } & $\alpha_{1}$ & -0.021 & $-3.367^{\star}$ & \multirow{2}{*}{0.604} & \multirow{2}{*}{ CDS } \\
\hline & $\alpha_{2}$ & 0.032 & $4.663^{*}$ & & \\
\hline \multirow{2}{*}{ Italy } & $\alpha_{1}$ & -0.006 & -1.032 & \multirow{2}{*}{ - } & \multirow{2}{*}{ CDS } \\
\hline & $\alpha_{2}$ & 0.019 & $2.720^{*}$ & & \\
\hline \multirow{2}{*}{ Greece } & $\alpha_{1}$ & 0.023 & $2.990^{*}$ & \multirow{2}{*}{-} & \multirow{2}{*}{ Unidentified } \\
\hline & $\alpha_{2}$ & -0.006 & -1.502 & & \\
\hline \multirow{2}{*}{ Spain } & $\alpha_{1}$ & 0.010 & 1.944 & \multirow{2}{*}{ - } & \multirow{2}{*}{ CDS } \\
\hline & $\alpha_{2}$ & 0.023 & $4.196^{\star}$ & & \\
\hline \multirow{2}{*}{ France } & $\alpha_{1}$ & -0.001 & -0.487 & \multirow{2}{*}{-} & \multirow{2}{*}{ CDS } \\
\hline & $\alpha_{2}$ & 0.017 & $5.235^{\star}$ & & \\
\hline \multirow{2}{*}{ Austria } & $\alpha_{1}$ & -0.009 & $-3.019^{\star}$ & \multirow{2}{*}{0.007} & \multirow{2}{*}{ Bond } \\
\hline & $\alpha_{2}$ & 0.020 & $5.334^{\star}$ & & \\
\hline
\end{tabular}

Note: This table reports the estimated speed of adjustment coefficients $\left(\alpha_{1}\right.$ and $\left.\alpha_{2}\right)$ and the Gonzalo-Granger measure $(G G)$. If $\alpha_{1}$ is significantly negative, the bond spread leads the pricing process. If $\alpha_{2}$ is significant and positive, the CDS spread is the leading one. If both coefficients are significant and correctly signed $\left(\alpha_{1}<0, \alpha_{2}>0\right)$, both spreads contribute to price discovery. In such a case, if $G G$ exceeds 0.5 the CDS spread leads bond spread and vice-versa. ${ }^{*}$ denotes significance at $5 \%$ level.

Completing our analysis over the entire sample period, we apply the conventional Granger causality test on the first differences and the bootstrap test on the levels for both the CDS and bond spreads. Table 5, illustrates that causality tests fail to identify the leading market for Portugal, Italy and Greece, indicating feedback causality. Considering Spain, France and Austria the results are rather conflicting.

Table 5. Granger causality test (full sample)

\begin{tabular}{|c|c|c|c|c|c|c|}
\hline & \multicolumn{3}{|c|}{ Conventional } & \multicolumn{3}{|c|}{ Bootstrap } \\
\hline & \multicolumn{2}{|c|}{ Null Hypothesis } & \multirow[b]{2}{*}{ Causality } & \multicolumn{2}{|c|}{ Null Hypothesis } & \multirow[b]{2}{*}{ Causality } \\
\hline & $\begin{array}{l}\text { No Causality } \\
\text { from CDS to } \\
\text { Bond spread }\end{array}$ & $\begin{array}{l}\text { No Causality } \\
\text { from Bond to } \\
\text { CDS spread }\end{array}$ & & $\begin{array}{l}\text { No Causality } \\
\text { from CDS to } \\
\text { Bond spread }\end{array}$ & $\begin{array}{l}\text { No Causality } \\
\text { from Bond to } \\
\text { CDS spread }\end{array}$ & \\
\hline Portugal & $972.873^{\star}(0.000)$ & $41.351^{\star}(0.000)$ & Feedback & $962.159^{*}(0.000)$ & $40.148^{\star}(0.000)$ & Feedback \\
\hline Italy & $12.530^{\star}(0.002)$ & $35.416^{*}(0.000)$ & Feedback & $14.623^{*}(0.001)$ & $33.672^{\star}(0.000)$ & Feedback \\
\hline Greece & $818.977^{\star}(0.000)$ & $212.167^{\star}(0.000)$ & Feedback & $815.627^{*}(0.000)$ & $206.673^{*}(0.000)$ & Feedback \\
\hline Spain & $26.029^{\star}(0.000)$ & $46.177^{\star}(0.000)$ & Feedback & $10.966(0.052)$ & $41.190^{*}(0.000)$ & $\begin{array}{c}\text { Bond } \rightarrow \\
\text { CDS }\end{array}$ \\
\hline France & $47.567^{\star}(0.000)$ & $4.623(0.099)$ & $\begin{array}{c}\text { CDS } \rightarrow \\
\text { Bond }\end{array}$ & $34.118^{*}(0.000)$ & $2.315^{\star}(0.002)$ & Feedback \\
\hline Austria & $106.161^{\star}(0.000)$ & $10.750^{*}(0.005)$ & Feedback & $92.731^{*}(0.000)$ & $3.3770(0.185)$ & $\begin{array}{c}\text { CDS } \rightarrow \\
\text { Bond }\end{array}$ \\
\hline
\end{tabular}

Note: This table reports the results of both conventional and bootstrap Granger causality tests. Columns 2, 3, 5 and 6 display the results of the $F$-tests. ${ }^{*}$ denotes the rejection of the null hypothesis of no causality at $5 \%$ level. 


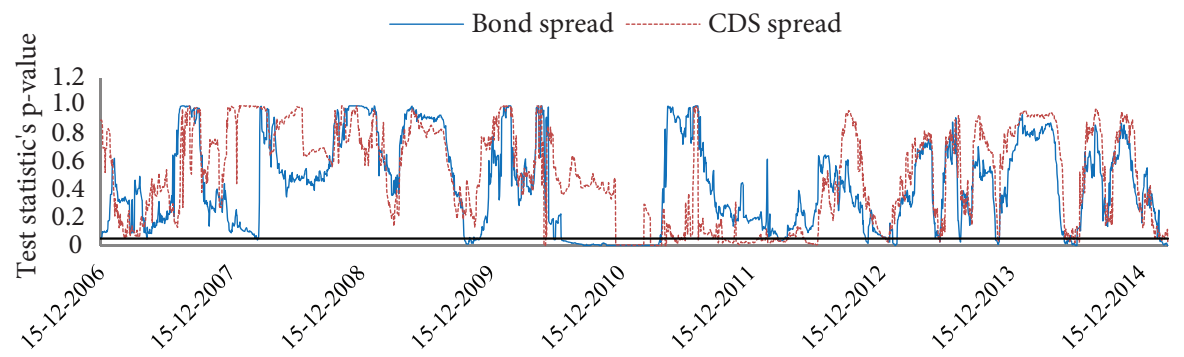

$1 \mathrm{~A}$

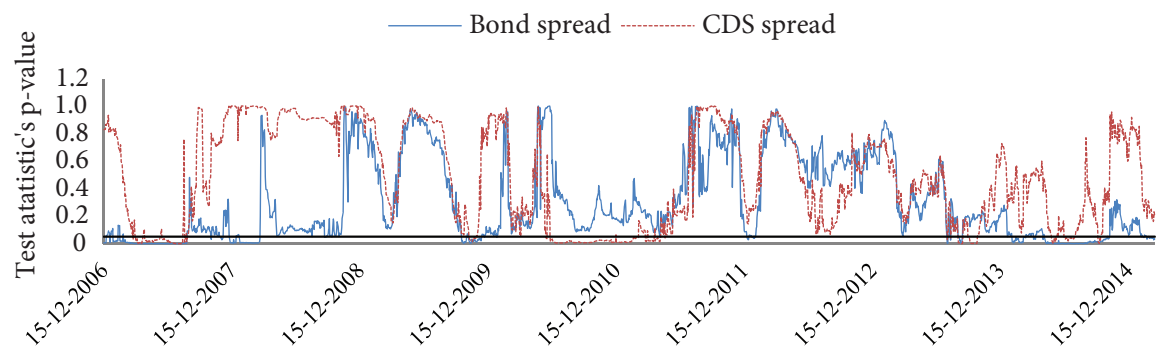

$1 \mathrm{~B}$

— Bond spread -..--..-.... CDS spread



$1 \mathrm{C}$

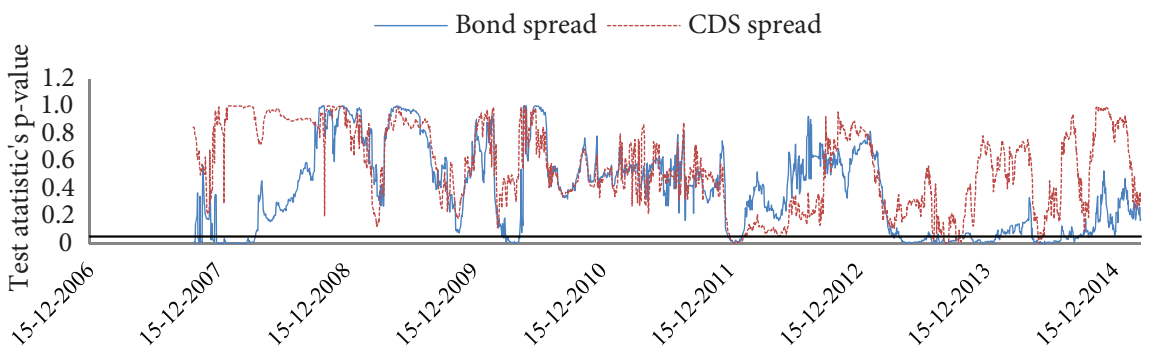

$1 \mathrm{D}$

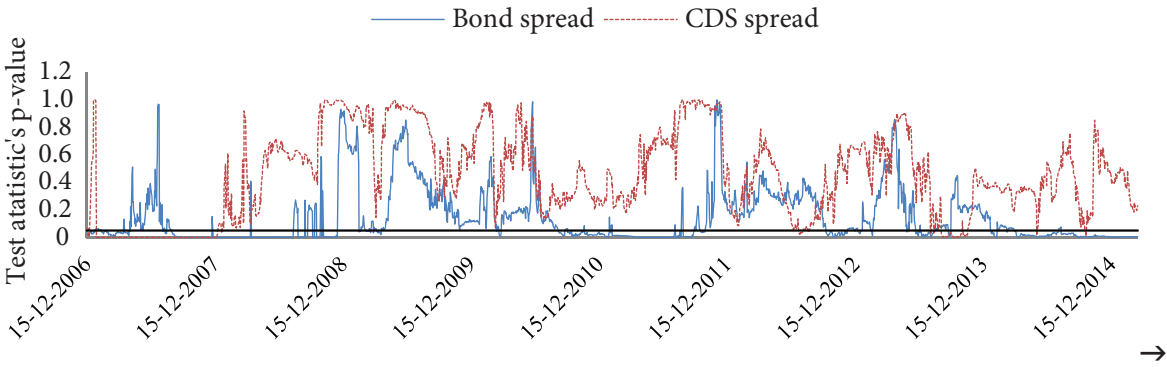




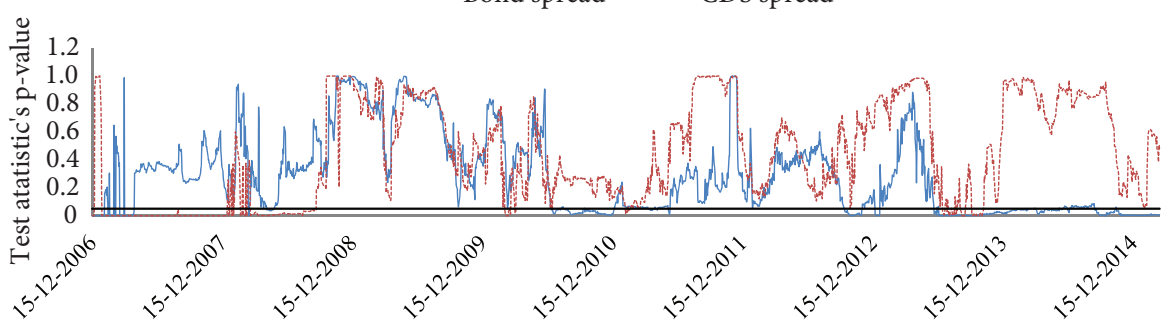

Figure 1. Rolling ADF test in levels for Portugal (1A), Italy (1B), Greece (1C), Spain (1D), France $(1 \mathrm{E})$ and Austria (1F). All the above figures present the $p$-values of the rolling window Dickey-Fuller test statistics for bond and CDS spreads of each country. The null hypothesis of unit root is only rejected at $5 \%$ significance level, during a few, short time periods. The $p$-values are reported on the last day of the window from which they are derived

The bootstrap Granger causality test attributes the price discovery leadership to the bond and CDS market for Spain and Austria, respectively. In the case of France, the conventional causality test provides evidence of causality from CDS to bond spread, highlighting the CDS market as the leading one in price discovery.

\section{Rolling window analysis}

The rolling ADF unit root test indicates that the examined series are, in general, non-stationary. The plots in Figures $1 \mathrm{~A}-\mathrm{F}$ illustrate that the unit root hypothesis is only rejected, at $5 \%$ significance level, during a few and short time periods. Strong evidence of stationarity is found in the first differences in the series across all the windows.

The above findings allow us to apply the Johansen cointegration test on 7.649 windows in total. The null hypothesis of no cointegration is rejected, at $5 \%$ significance level, in 2.727 windows, indicating that in most cases there is no long-run equilibrium relationship between CDS and bond spreads. Greece presents the highest percentage of cointegration relationships with cointegration in $44 \%$ of the windows, while the lowest percentage is observed in the case of Spain with cointegration in $23 \%$ of the windows. Table 6 summarizes the results of the cointegration test.

Table 6. Cointegration test

\begin{tabular}{|l|c|c|c|}
\hline \multirow{2}{*}{} & \multicolumn{3}{|c|}{ Windows } \\
\cline { 2 - 4 } & Examined & Cointegration & Cointegration Existence (\%) \\
\hline Portugal & 1.652 & 673 & $41 \%$ \\
\hline Italy & 1.435 & 515 & $36 \%$ \\
\hline Greece & 993 & 433 & $44 \%$ \\
\hline Spain & 1.509 & 352 & $23 \%$ \\
\hline France & 933 & 292 & $31 \%$ \\
\hline Austria & 1.127 & 462 & $41 \%$ \\
\hline Total & 7.649 & 2.727 & $36 \%$ \\
\hline
\end{tabular}

Note: This table summarizes the results of the Johansen cointegration test. Column 2 displays the number of windows for which the Augmented Dickey-Fuller unit root test indicates that both CDS and bond spread series are integrated in the first differences. Columns 3 and 4 display the number and the respective percentages of windows for which evidence of cointegration is found. 


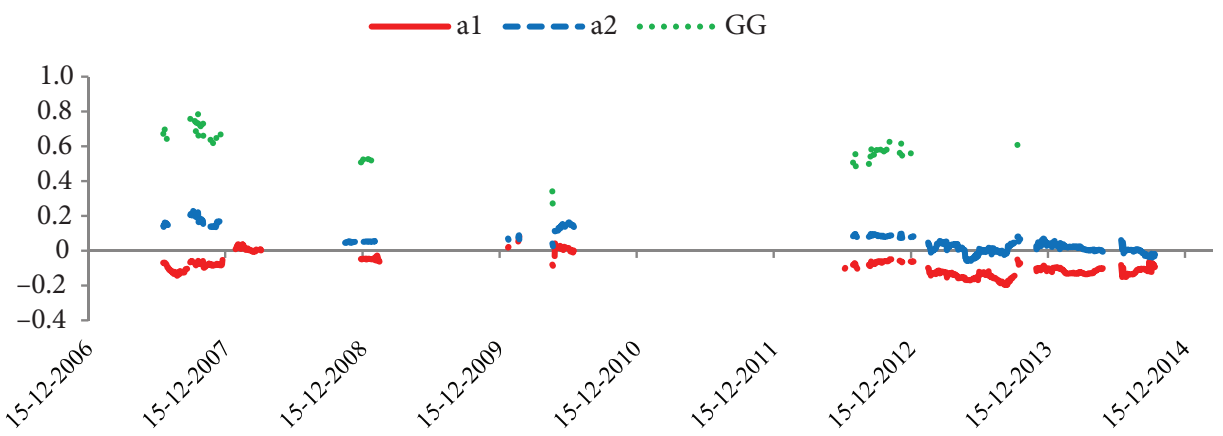

2A
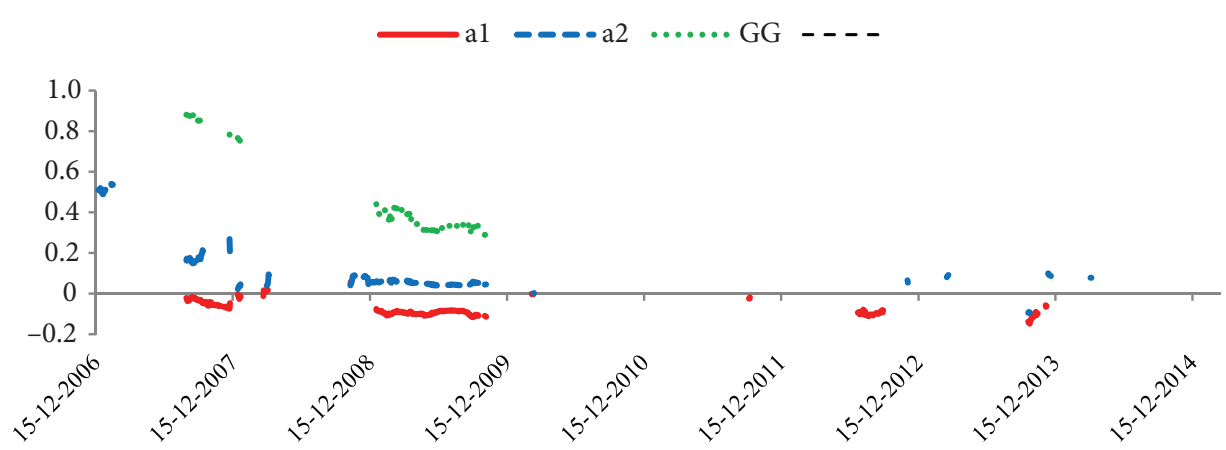

2B
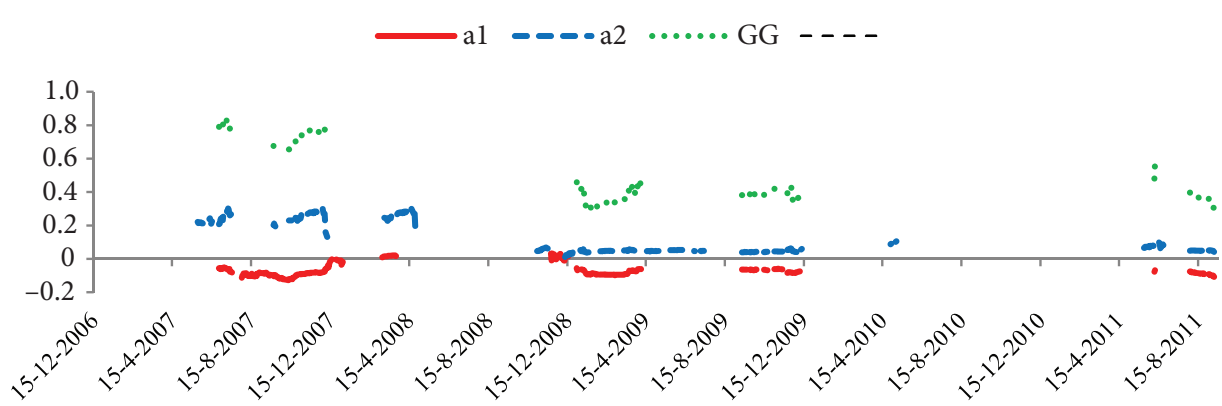

2C



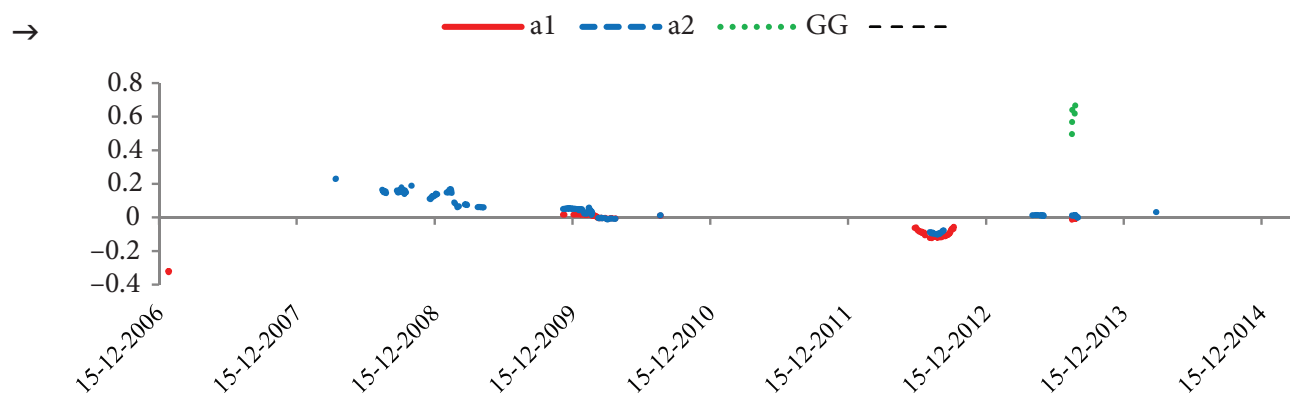

$2 \mathrm{E}$

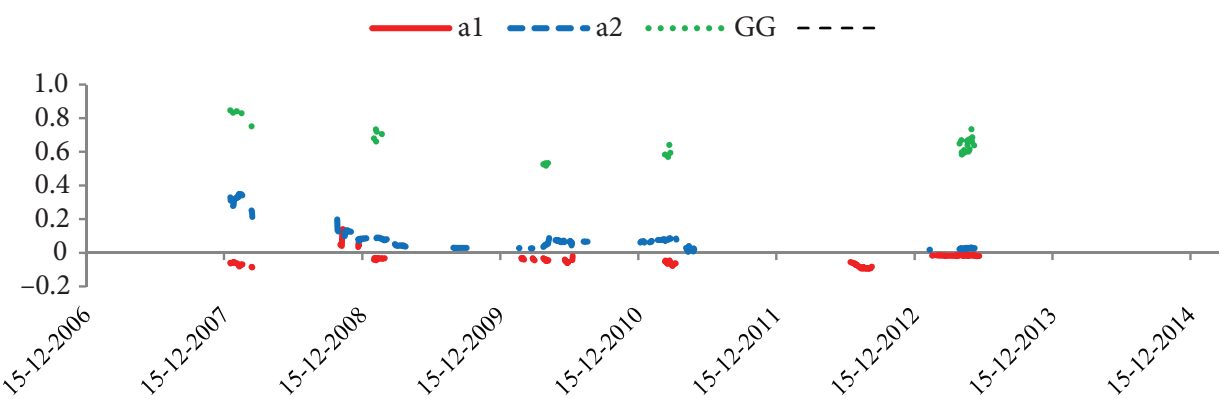

Figure 2. Price Discovery Measures for Portugal (2A), Italy (2B), Greece (2C), Spain (2D), France (2E) andAustria (2F). All the above figures report the estimated speed of adjustment coefficients ( and ) and the GG measure from the windows in which we find evidence of cointegration. If is significantly negative, the bond spread leads the price discovery process. If is significant and positive, the CDS spread is the leading one in price discovery. If both coefficients are significant and correctly signed (), both markets contribute to price discovery. In such a case, if $G G$ exceeds 0.5 the CDS spread leads bond spread and vice-versa. We only report the statistically significant (at $5 \%$ level) speed of adjustment coefficients. All the measures are reported on the last day of the window from which they derived

Focusing on the windows in which we find evidence of cointegration, CDS and bond spreads are examined in a VECM framework in order to investigate the adjustment process in the short-run. Figures 2A-F report the estimated speed of adjustment coefficients $\left(\alpha_{1}\right.$ and $\alpha_{2}$ ) and the $G G$ measure.

Considering the windows in which the null hypothesis of no cointegration is not rejected, we implement the Granger causality test estimating VAR models of order $p$ in first differences form of CDS and bond spreads, with the intention to determine the price discovery process. Regarding the windows in which we find that both spreads' series are level stationary, we implement the Granger causality test estimating $\operatorname{VAR}(p)$ models in level form of the two spreads. Nevertheless, it is worth noting that there are windows for which the leading market cannot be identified for three reasons: (a) feedback causality is detected, (b) the interpretation of speed of adjustment coefficients $\left(\alpha_{1}\right.$ and $\left.\alpha_{2}\right)$ is meaningless, and (c) the price discovery methodology cannot be implemented. Table 7 briefly presents the results of the price discovery analysis. Apparently, empirical results strongly suggest that the price discovery process takes place neither continuously in the same direction nor with the same intensity, verifying the indications of Delatte et al. (2012) and being in line with Delis and Mylonidis (2011) and 
Arce et al. (2013). Indeed, price discovery evolves over time, while the direction of influence from the CDS market to the bond market, and vice-versa, exhibits frequent alternations. The next paragraphs present the country-specific analysis of the price discovery results.

Table 7. Price discovery leadership

\begin{tabular}{|l|c|c|c|c|c|c|c|}
\hline & \multicolumn{9}{|c|}{ Windows } \\
\cline { 2 - 9 } & Examined & \multicolumn{1}{|c|}{ CDS Market Leadership } & \multicolumn{2}{|c|}{ Bond Market Leadership } & \multicolumn{2}{|c|}{ Unidentified } \\
\hline Portugal & 2.135 & 729 & $34 \%$ & 535 & $25 \%$ & 871 & $41 \%$ \\
\hline Italy & 2.144 & 329 & $15 \%$ & 417 & $20 \%$ & 1.398 & $65 \%$ \\
\hline Greece & 1.240 & 658 & $53 \%$ & 228 & $18 \%$ & 354 & $29 \%$ \\
\hline Spain & 1.930 & 463 & $24 \%$ & 407 & $21 \%$ & 1.060 & $55 \%$ \\
\hline France & 2.145 & 246 & $12 \%$ & 67 & $3 \%$ & 1832 & $85 \%$ \\
\hline Austria & 2.145 & 651 & $30 \%$ & 224 & $11 \%$ & 1270 & $59 \%$ \\
\hline Total & 11.739 & 3.076 & $26 \%$ & 1.878 & $16 \%$ & 6.785 & $58 \%$ \\
\hline
\end{tabular}

Notes: This table displays the overall results of the integrated price discovery analysis conducted on each time window. Column 2 displays the total number of the examined time windows. Columns 3 and 4 display the number and the respective percentages of windows for which CDS market leadership is found. Columns 5 and 6 display the number and the respective percentages of windows for which bond market leadership is found. Columns 7 and 8 display the number and the respective percentages of windows for which the leading market cannot be identified.

As far as Portugal is concerned, we find that for most of the pre-crisis period the leading market in price discovery cannot be identified (70\% of the windows). The CDS market generally leads the price discovery process from the end of 2008 until the end of October 2012. The above period is characterized as particularly turbulent and risky, since it includes the unfolding of the debt crisis in the heavily indebted European countries. Specifically, in April 2011 Portugal requests help from the EU, admitting that it is not able to deal with its financial needs. In May 2011, the EU and the IMF approve a $€ 78$ billion bailout package for Portugal. However, by January 2012, Portugal has its debt downgraded to non-investment grade (or junk) status by the Big Three credit rating agencies (Moody's, S\&P, and Fitch). As a result, the five-year government bond yield spread and the corresponding sovereign CDS spread reach to euro-era historical highs. The bond market moves ahead of the CDS market from the end of January 2013, coinciding with a substantial reduction of CDS and bond spreads, and remains there until the end of the sample. It is worth noticing that in August 2013, economic indicators start signaling Portugal's recovery from recession, while in May 2014 the Portuguese government announces that it has completed the terms of the bailout agreement.

Taking Italy into consideration, empirical findings regarding the leading market in the price discovery process are unclear. We find that the bond market explicitly leads in price discovery only from the end of 2008 to the end of September 2009. During this period, there is relatively little concern about the European sovereign debt. Sovereign credit markets still remain relatively calm while Italian sovereign CDS and bond spreads are in particularly low levels. Subsequently, CDS and bond markets alternately and for short time periods take up the leading role in price discovery. Interestingly, for most of the time in the short-run nei- 
ther the CDS nor the bond market can be identified as the price leader. The most significant periods during which the leading market cannot be determined are: (a) from the end of March 2008 to the end of October 2008, (b) from the June 2010 to the end of February 2011, (c) from the end of November 2011 to July 2012, (d) from the beginning of April 2013 to October 2013 and (e) from the end of March 2014 to the end of February 2015.

Concerning Greece, it is evident that for most of the examined period, especially after the outbreak of the global financial crisis, price discovery takes place in the CDS market (53\% of the windows). During the early stages of the European debt crisis, the government bond market seems to lead the corresponding CDS market in terms of price discovery. However, the bond market loses the leading role in favor of the CDS market in April 2009, when Greece first receives the EU mandate to reduce its budget deficit. CDS market maintains the leadership in price discovery for almost a five-month period (until the start of September 2009). Then, for the next three months, the leading role cannot be clearly attributed either to the CDS market or to the bond market. Following this, the CDS market becomes once again the leader in terms of price discovery from the start of December 2009 to mid-April 2010. The CDS market's rebound coincides with the revelation that Greece's sovereign debt burden amounts to $113 \%$ of GDP ( $€ 300$ billions). At the same time, credit rating agencies start to downgrade the Greek debt to non-investment grade status and the Greek borrowing costs skyrocket. There follows a considerable period (from April 2010 to July 2010) for which the leading market in price discovery cannot be determined. During this period and specifically in May 2010, the EU, the ECB and the IMF agree to a $€ 110$ billion bailout package to Greece. The CDS market retrieves the leading role in the start of August 2010 and up to mid-July 2011, when European leaders agree on an additional $€ 109$ billion package to Greece, intending to stabilize the Eurozone as a whole and prevent contagion effects to other economies. In August 2011 and until the end of the sample, the bond market moves ahead of the CDS market. The latter finding is in line with Arce et al. (2013).

Regarding Spain, we initially find that price discovery takes place in the CDS market. The bond market moves ahead of the CDS market in mid-January 2009. However, the CDS market resumes the leading role at the end of November 2009, when concerns about the heavily indebted European countries, including Spain, begin to grow. The CDS market loses the leading role in mid-March 2011, about a month after the Eurozone member states announce the creation of a permanent $€ 500$ billion bailout fund, called European Stability Mechanism (ESM). The bond market retrieves the leading role in price discovery at the end of September 2011 and remains the leader until the beginning of March 2012. Then, a considerable period (from March 2012 to January 2014) follows for which the leading market cannot be identified. Within this period, Spain's borrowing costs rise, reaching their highest level since the launch of the euro in July 2012. Lastly, approaching to the end of the sample, two (relatively short) periods of bond market leadership are observed, while Spain's CDS and bond spreads exhibit a downward trend. Specifically, we find that price discovery takes place in bond market from the end of January 2014 to mid-April 2014 and from the end of August 2014 to mid-October 2014.

On the whole, the empirical results of our research indicate the regularity that under stressful conditions the CDS market leads the price discovery process. During periods of 
increased uncertainty, when government bonds become risky, illiquid and their spreads rise sharply, the CDS spreads incorporate any new information on sovereign credit risk timely and efficiently, being the most representative credit risk measure. Therefore, the CDS spreads can be considered as more precise market indicators than bond spreads, especially concerning asset pricing and sustainability of fiscal policy measures. On the contrary, reliance on bond market movements during high-risk periods can result in asymmetry effects, hampering the investment and funding decision-making process of private and institutional market participants. Credit markets, just like any financial market, are a useful source of information for decision-makers, having a real effect on economic activity. The sovereign CDS and bond markets may contain different pieces of information due to different price movements of the underlying assets. At certain points during an economic turmoil, the bond spreads might reflect a relatively moderate market perception of public finances and future economic perspectives, resulting in government complacency. At the same time, the CDS spreads probably send out warning signals for urgent policy measures, which, however, tend to be downplayed. Apparently, the two markets provide diverse information causing asymmetric effects in terms of government policy action as well as investment strategies. Considering the leading role of CDS spreads, bond spreads could be treated as lagging indicators of credit risk and thus incapable of proactive and rational decision-making.

The above findings contradict Arce et al. (2013) and Delis and Mylonidis (2011), who also employ rolling window estimation techniques. In particular, Arce et al. (2013) argue that the intensification of the debt crisis in Europe after 2011 highlighted the leading role of the bond market in the pricing process, while Delis and Mylonidis (2011) provide evidence of feedback causality between CDS and bond markets during periods of financial distress. This differentiation can be attributed to two main reasons. First, the sampling periods of Arce et al. (2013) and Delis and Mylonidis (2011) end in the very early 2010s. Our study considers the period from 2006 to 2015, taking into account the latest developments in sovereign indebtedness. Second, we apply an integrated price discovery analysis on each time window rather than single price discovery measures. The previous dynamic studies employ either the Granger causality test (Delis \& Mylonidis, 2011) or the Gonzalo and Granger measure (Arce et al., 2013), failing to provide clear evidence for a significant number of time windows.

In order to check the validity of our findings, we apply our dynamic price discovery analysis beyond the heavily indebted southern Eurozone countries, also considering France and Austria. The perceived sovereign credit risk and, thus, CDS and bond spreads of these two core Eurozone countries are at considerably lower levels than in the other countries examined. Indeed, France and Austria are characterized by mean CDS and bond spreads well below 100 basis points over the examined period.

As far as core Eurozone countries are concerned, the empirical results regarding the leading market in price discovery are unclear. France presents the highest percentage of windows (85\%) for which the leading market cannot be identified. The CDS market explicitly leads in price discovery only from the beginning of January 2012 to the end of March 2012. This period succeeds the historical highs of French CDS and bond spreads at the end of 2011. In the case of Austria, the leading market cannot be detected for most of the examined period (59\% of the windows). However, we find significant periods of CDS market leadership (from 
September 2008 to June 2009 and from April 2011 to March 2012). Interestingly, regarding the examined time sample, the highest levels of Austrian CDS and bond spreads are observed within these periods. The above findings confirm the regularity that during periods of increased uncertainty the CDS market leads the price discovery process.

\section{Conclusions}

The present study confirms that price discovery is a time-varying process exhibiting frequent alternations in terms of leadership. The direction of influence from the CDS market to the bond market, and vice-versa, depends on the specific financial characteristics of the sample in question. Concerning the over-indebted southern Eurozone countries, after examining the stationarity of bond and CDS spreads' series and, then, the existence (or not) of a long-run equilibrium relationship between them, the VECM and the Granger causality test suggest the following:

Greece demonstrates the highest percentage of CDS spread leadership (53\% of the windows), while the lowest percentage is observed in the case of Italy ( $15 \%$ of the windows).

Bond spread is found to lead the price discovery process in 25\%,20\%, 18\% and $21 \%$ of the windows for Portugal, Italy, Greece and Spain, respectively.

There is a significant number of windows for which the leading market cannot be identified, especially in the case of Italy (65\% of the windows).

The empirical results let us determine, in principle, the regularity that, during periods of financial turmoil, the CDS market leads the bond market in price discovery incorporating the information about sovereign risk, faster and more efficiently than the bond market does. Respectively, an increase in the CDS spread leads to an increase of the corresponding bond spread, raising the sovereign cost of borrowing as well as affecting inflation and foreign exchange rates. The evidence from core Eurozone countries further enhances the validity of this observation. Indeed, we find that periods of CDS market leadership in price discovery either succeed (France) or coincide with (Austria) significant rises in perceived sovereign credit risk.

Under such circumstances, rational investment decisions and proper application of fiscal policy measures, inevitably require close and greater attention to CDS market developments. Considering the information efficiency of the CDS market, financial regulatory authorities and supervisory agencies should make policy decisions that will further enhance the liquidity and reliability of the credit derivatives market. The European Market Infrastructure Regulation (EMIR) introduced the central clearing obligation for OTC derivative contracts through a central counterparty (CCP) and the mandatory reporting for derivative counterparties of all contract details to a trade repository (TR) authorised by the European Securities and Markets Authority (ESMA). However, a critical challenge that remains in the CDS market is the need for more post-trade transparency. A critical step towards more transparent credit markets and a more strengthened financial system would be the initiation of an organised exchange or electronic trading platform for sovereign CDS trading, in line with the statement of the 2009 G-20 Summit that "All standardized OTC derivative contracts should be traded on exchanges or electronic trading platforms, where appropriate". Trading on organised markets will bring 
the final standardization of CDS contracts, which in turn will facilitate their clearing and eliminate documentation risk. Market participants will also exploit the usual advantages of an organized market, such as the provision of continuous pricing, the imposition of trading limits, the ability of placing various order types and the availability of detailed market data information. Therefore, the transition from an OTC to an organised venue is expected to enhance the transparency of the CDS market and attract a wider pool of investors, generating more liquidity in the market.

Nevertheless, our research is subject to caveats worth noting. We investigate the relation between sovereign CDS and bond spreads for a sample of euro area countries without considering sovereigns beyond the Eurozone facing similar financial difficulties. Widening the sample, including countries in a similar economic situation, could lead to different conclusions. Also, our study examines the linkage between the two credit markets during a period of increased economic uncertainty. It is possible that different behavior may be displayed by both markets in periods of reduced uncertainty and/or economic growth. Last but not least, we reach our conclusions utilizing daily data on rolling windows with approximately a calendar year observations. It would be challenging to confirm the results of our study using weekly and/or monthly data on windows with a duration of less than or greater than a year. In this context and beyond addressing the above limitations, the findings of our study could raise issues for further research. Scholars in the field could focus on the investigation of the specific determinants of the leading market in the price discovery process. Besides, they may reconsider the relation between CDS and bond markets from the perspective of efficiency and transparency, in order to suggest measures and reforms that will eliminate asymmetric information effects.

\section{Disclosure statement}

The authors have no competing financial, professional, or personal interests from other parties that are related to the subject of this paper.

\section{References}

Aktug, R., Vasconcellos, G., \& Bae, Y. (2012). The dynamics of sovereign credit default swap and bond markets: empirical evidence from the 2001 to 2007 period. Applied Economics Letters, 19(3), 251259. https://doi.org/10.1080/13504851.2011.572839

Ammer, J., \& Cai, F. (2011). Sovereign CDS and bond pricing dynamics in emerging markets: Does the cheapest-to-deliver option matter? Journal of International Financial Markets, Institutions and Money, 21(3), 369-387. https://doi.org/10.1016/j.intfin.2011.01.001

Andraz, J., Viegas, C. M., \& Norte, N. M. (2015, 6-9 October). New insights on the long-term relationship between sovereign bonds debt and credit default swaps in Portugal. In IISES 2015: Proceedings of the International Academic Conference, International Institute of Social and Economic Sciences. Madrid, Spain.

Arce, O., Mayordomo, S., \& Peña, J. I. (2013). Credit-risk valuation in the sovereign CDS and bonds markets: Evidence from the euro area crisis. Journal of International Money and Finance, 35, 124145. https://doi.org/10.1016/j.jimonfin.2013.01.006 
Baba, N., \& Inada, M. (2007). Price discovery of credit spreads for Japanese mega-banks: Subordinated bond and CDS. IMES Discussion Paper, No. 2007-E-6.

Beber, A., Brandt, M. W., \& Kavavejc, K. A. (2009). Flight-to-quality or flight-to-liquidity? Evidence from the Euro-Area bond market. Review of Financial Studies, 22(3), 925-957. https://doi.org/10.1093/rfs/hhm088

Blanco, R., Brennan, S., \& Marsh, I. W. (2005). An empirical analysis of the dynamic relation between investment - grade bonds and credit default swaps. The Journal of Finance, 60(5), 2255-2281. https://doi.org/10.1111/j.1540-6261.2005.00798.x

Bowe, M., Klimaviciene, A. \& Taylor, A. P. (2009, 4-7 March). Information transmission and price discovery in emerging sovereign credit risk markets. Paper presented at the Mid-West Finance Association Annual Conference, Chicago, USA.

Chan-Lau, J. A., \& Kim, Y. S. (2004). Equity prices, credit default swaps, and bond spreads in emerging markets. IMF Working Paper, No. 04/27. https://doi.org/10.5089/9781451844559.001

Cossin, D., \& Lu, H. (2005). Are European corporate bonds and default swap markets segmented?. Working Paper 153, FAME. https://doi.org/10.2139/ssrn.680464

Coudert, V., \& Gex, M. (2013). The interactions between the credit default swap and the bond markets in financial turmoil. Review of International Economics, 21(3), 492-505. https://doi.org/10.1111/roie.12050

Coudert, V., \& Gex, M. (2010). Credit default swap and bond markets: which leads the other. Banque de France-Financial Stability Review, 14, 161-167.

Delatte, A. L., Gex, M., \& López-Villavicencio, A. (2012). Has the CDS market influenced the borrowing cost of European countries during the sovereign crisis?. Journal of International Money and Finance, 31(3), 481-497. https://doi.org/10.1016/j.jimonfin.2011.10.008

Delis, M. D., \& Mylonidis, N. (2011). The chicken or the egg? A note on the dynamic interrelation between government bond spreads and credit default swaps. Finance Research Letters, 8(3), 163-170. https://doi.org/10.1016/j.frl.2010.09.005

Dickey, D. A., \& Fuller, W. A. (1979). Distribution of the estimators for autoregressive time series with a unit root. Journal of the American statistical association, 74(366), 427-431. https://doi.org/10.2307/2286348

Duffie, D. (1999). Credit swap valuation. Financial Analysts Journal, 55(1), 73-87. https://doi.org/10.2469/faj.v55.n1.2243

European Central Bank. (2004). The Euro bond market study. ECB, Frankfurt.

Fontana, A., \& Scheicher, M. (2016). An analysis of euro area sovereign CDS and their relation with government bonds. Journal of Banking \& Finance, 62, 126-140. https://doi.org/10.1016/j.jbankfin.2015.10.010

Forte, S., \& Pena, J. I. (2009). Credit spreads: An empirical analysis on the informational content of stocks, bonds, and CDS. Journal of Banking \& Finance, 33, 2013-2025. https://doi.org/10.1016/j.iref.2013.10.003

Gonzalo, J., \& Granger, C. (1995). Estimation of common long-memory components in cointegrated systems. Journal of Business \& Economic Statistics, 13(1), 27-35. https://doi.org/10.1080/07350015.1995.10524576

Granger, C. (1969). Investigating causal relations by econometric models and cross-spectral methods. Econometrica: Journal of the Econometric Society, 37(3), 424-438. https://doi.org/10.2307/1912791

Greene, W. H. (2003). Econometric analysis. India: Pearson Education.

Group of 20. (2009). Leaders' statement: The Pittsburgh Summit. Retrieved from https://www.oecd.org/ g20/summits/pittsburgh/G20-Pittsburgh-Leaders-Declaration.pdf

Gujarati, D. N. (2003). Basic econometrics (4th ed.). New York: McGraw-Hill. 
Gyntelberg, J., Hördahl, P., Ters, K., \& Urban, J. (2017). Arbitrage costs and the persistent non-zero CDS-bond basis: Evidence from intraday euro area sovereign debt markets. BIS Working Paper, No. 631 .

Hassan, M. K., Ngene, G. M., \& Suk-Yu, J. (2015). Credit default swaps and sovereign debt markets. Economic Systems, 39(2), 240-252. https://doi.org/10.1016/j.ecosys.2014.07.002

Hull, J. C., \& White, A. D. (2000). Valuing credit default swaps I: No counterparty default risk. The Journal of Derivatives, 8(1), 29-40. https://doi.org/10.3905/jod.2000.319115

Hull, J., Predescu, M., \& White, A. (2004). The relationship between credit default swap spreads, bond yields, and credit rating announcements. Journal of Banking \& Finance, 28(11), 2789-2811. https://doi.org/10.1016/j.jbankfin.2004.06.010

Ito, T. (2016). The behaviour of sovereign CDS and government bond in the Euro zone crisis. International Journal of Monetary Economics and Finance, 9(2), 102-114. https://doi.org/10.1504/IJMEF.2016.076478

Jeffrey, M. W. (2009). Introductory econometrics: A modern approach. Canada: South-Western Cengage Learning.

Johansen, S. (1991). Estimation and hypothesis testing of cointegration vectors in Gaussian vector autoregressive models. Econometrica: Journal of the Econometric Society, 59(6), 1551-1580. https://doi.org/10.2307/2938278

Klenina, E., \& Mateus, C. (2017). Global financial crisis and price discovery between credit default swaps premia and bond yield spreads. Retrieved from https://ssrn.com/abstract=3025003.

Klieštik, T., \& Cúg, J. (2015). Comparison of selected models of credit risk. Procedia Economics and Finance, 23, 356-361. https://doi.org/10.1016/S2212-5671(15)00452-9

Kollias, C., Mylonidis, N., \& Paleologou, S. M. (2012). The nexus between exchange rates and stock markets: evidence from the euro-dollar rate and composite European stock indices using rolling analysis. Journal of Economics and Finance, 36(1), 136-147.

https://doi.org/10.1007/s12197-010-9129-8

Kregzde, A., \& Murauskas, G. (2015). Analysis of Lithuanian credit default swaps. Journal of Business Economics and Management, 16(5), 916-930. https://doi.org/10.3846/16111699.2014.890130

Lee, J., Naranjo, A., \& Velioglu, G. (2017). When do CDS spreads lead? rating events, private entities, and firm-specific information flows. Journal of Financial Economics, Forthcoming. Retrieved from https://ssrn.com/abstract=2933052.

Longstaff, F. A., Mithal, S., \& Neis, E. (2003). The credit-default swap market: is credit protection priced correctly?. Working Paper, University of California.

Mylonidis, N., \& Kollias, C. (2010). Dynamic European stock market convergence: Evidence from rolling cointegration analysis in the first euro-decade. Journal of Banking \& Finance, 34(9), 2056-2064. https://doi.org/10.1016/j.jbankfin.2010.01.012

Ngene, G. M., Benefield, P., \& Lynch, A. K. (2018). Asymmetric and nonlinear dynamics in sovereign credit risk markets. Journal of Futures Markets, 38(5), 563-585. https://doi.org/10.1002/fut.21896

Nguyen, N. B. (2017). The price discovery mechanism between sovereign bond and sovereign CDS market: Studies in selected countries. Asian Journal of Finance \& Accounting, 9(2), 270-286. https://doi.org/10.5296/ajfa.v9i2.11636

Nyakabawo, W., Miller, S. M., Balcilar, M., Das, S., \& Gupta, R. (2015). Temporal causality between house prices and output in the US: A bootstrap rolling-window approach. The North American Journal of Economics and Finance, 33, 55-73. https://doi.org/10.1016/j.najef.2015.03.001

Norden, L., \& Weber, M. (2009). The co-movement of credit default swap, bond and stock markets: an empirical analysis. European financial management, 15(3), 529-562.

https://doi.org/10.1111/j.1468-036X.2007.00427.x 
Palladini, G., \& Portes, R. (2011). Sovereign CDS and bond pricing dynamics in the euro-area. NBER Working Paper, No. 17586. https://doi.org/10.3386/w17586

Swanson, N. R. (1998). Money and output viewed through a rolling window. Journal of Monetary Economics, 41(3), 455-474. https://doi.org/10.1016/S0304-3932(98)00005-1

Toda, H. Y., \& Yamamoto, T. (1995). Statistical inference in vector autoregressions with possibly integrated processes. Journal of Econometrics, 66(1-2), 225-250. https://doi.org/10.1016/0304-4076(94)01616-8

Trujillo-Ponce, A., Samaniego-Medina, R., \& Cardone-Riportella, C. (2014). Examining what best explains corporate credit risk: accounting-based versus market-based models. Journal of Business Economics and Management, 15(2), 253-276. https://doi.org/10.3846/16111699.2012.720598

Yin, K., Liu, Z., \& Liu, P. (2017). Trend analysis of global stock market linkage based on a dynamic conditional correlation network. Journal of Business Economics and Management, 18(4), 779-800. https://doi.org/10.3846/16111699.2017.1341849

Zivot, E., \& Andrews, D. (1992). Further evidence of the great crash, the oil-price shock and the unitroot hypothesis. Journal of Business and Economic Statistics, 10(3), 251-270. https://doi.org/10.1198/073500102753410372

Zhu, H. (2006). An empirical comparison of credit spreads between the bond market and the credit default swap market. Journal of Financial Services Research, 29(3), 211-235. https://doi.org/10.1007/s10693-006-7626-x 